\title{
Possible electronic mechanisms of generation and quenching of luminescence of singlet oxygen in the course of photodynamic therapy: $a b$ initio study
}

\author{
B. F. Minaev, L. B. Yashchuk \\ Cherkassy State University of Technology \\ Blvd. Shevchenko, 460, Cherkassy, 18006, Ukraine \\ leta@chiti.uch.net, yashchuk@yandex.ru
}

\begin{abstract}
On the basis of ab initio quantum chemical calculations the strong enhancement of the ${ }^{1}\left(a^{\mathrm{I}} \Delta_{\mathbf{B}} \cdot S_{0}\right) \rightarrow$ ${ }^{i}\left(X^{3} \Sigma_{g}^{-} \cdot T\right)$ transition in collision complex between $O_{2}$ and organic dye is predicted, where $T$ is the triplet excited state of the dye and $S_{0}$ is its ground singlet state. The collision-induced electric dipole transition moment depends on polarizability of the dye and can be used for the estimation of energy transfer rate constant. Quantum chemical calculations can predict the most efficient dye sensibilizer for photodynamic therapy of cancer, instead of the difficult experimental search. Some new ideas are proposed for additional laser simulated mechanisms of active oxygen generation.
\end{abstract}

Key words: singlet, triplet, complex of collision, transition moment, spin-orbit coupling.

Life strongly depends on kinetic barriers to oxidation by $\mathrm{O}_{2}$, determined by spin prohibition. In aerobic metabolism the molecular oxygen is required as the terminal electron acceptor in respiration and as a reagent for direct biochemical synthesis. Oxygen is a stable biradical with two unpaired electrons generating the electronic triplet ground state. Triplet oxygen from the air has sluggish reactivity with organic substrates in spite of the strong thermodynamic drive: oxidation to water and $\mathrm{CO}_{2}$ is strongly exothermic. Insertion of the triplet oxygen into organic molecules with all spins paired is a spin-forbidden process [1]. Enzymes activate $\mathrm{O}_{2}$ in order to overcome this spin-prohibition. The higher energy and greater reactivity of singlet oxygen is a major contributing factor in maintaining the constant level of triplet oxygen in the terrestrial atmosphere. In recent years the singlet oxygen, $\mathrm{O}_{2}\left(a^{\mathrm{i}} \Delta_{g}\right)$, is getting more and more important in biochemistry and photobiology. The $\mathrm{O}_{2}\left(a^{\prime} \Delta_{g}\right)$ species has now obtained regulatory (C) B. F. MINAEV, L. B. YASHCHUK, 2006 approval in most countries for the treatment of several types of tumors, most importantely, in photodynamic therapy of cancer $[2,3]$. Thus a simple two-atomic molecule, $\mathrm{O}_{2}$, provides numerous puzzles in chemistry of combustion and respiration, in photophysics of dye-containing air-saturated solvents, in photobiology and laser-induced photodynamic therapy of cancer [1]. With two singlet states lying close above its ground triplet state, the $\mathrm{O}_{2}$ molecule possesses a unique open-shell $\pi_{g}{ }^{2}$ configuration, which gives rise to very peculiar photochemical and photophysical processes in presence of intense laser fields. Photosensitized generation of the first excited state, $\mathrm{O}_{2}$ $\left(a^{1} \Delta_{g}\right)$, can be used in numerous applications, from chemical synthesis and cancer treatment to a new type of cell microscope $[1-4]$. The aim of the present paper is to provide theoretical arguments for a new mechanism of photosensitized generation of the excited singlet state oxygen, $\mathrm{O}_{2}\left(a^{\prime} \Delta_{g}\right)$, which explain the purposeful choice of sensibilizers in photodynamic therapy of cancer. 
Studies of generation mechanisms for singlet oxygen and its quenching in solvents have almost $\mathbf{4 0}$ years history. Krasnovsky first observed the $a^{t} \Delta_{g}-$ $-X^{3} \Sigma_{g}^{-}$luminescence in photosensitization experiments in solvents [4]. He used a special phosphorescope equipped with a near-IR photomultiplier for detection of very weak emission at $1270 \mathrm{~nm}$ in $\mathrm{CCl}_{4}$. This solvent is a non-efficient quencher of $\mathrm{O}_{2}\left(a^{1} \Delta_{g}\right)$, because of the absence of $\mathrm{C}-\mathrm{H}$ bonds. Krasnovsky first measured the radiative rate constant $k_{a-X}$ of the $a^{1} \Delta_{g} \rightarrow X^{3} \Sigma_{g}^{-}$emission by its quantum yield $Q_{r}$ estimation and by measurements of quantum yield $Q_{\Delta}$ of the $\mathrm{O}_{2}\left(a^{\prime} \Delta_{g}\right)$ generation and its lifetime $\tau_{\Delta}: k_{a-X}=$ $=Q_{r} / \tau_{\Delta} Q_{\Delta}[5]$. These measurements of quantum yields were done in $\mathrm{CCl}_{4}$ and in aliphatic hydrocarbons solvents; they resulted in negligible solvent dependence of $k_{a-X}$ values. Later it was shown that $k_{a-X}$ increase with solvent polarizability in aromatic and other nonsaturated solvents [1]. This was especially important in connection with numerous photobiological application, since the $a^{1} \Delta_{g} \rightarrow X^{3} \Sigma_{g}^{-}$emission was detected in biopolymers and even in the heart of rats. In the late eighties there were a lot of discussions and controversials about the relatively weak (10 times) solvent dependence of $k_{a-X}$, but the striking fact that this value is thousands times higher in comparison with a free molecule did not receive much attention $[1,4-6]$. The theory of this striking effect was proposed in $1982[7,8]$ just after Krasnovsky's measurements [5]. It is based on the symmetry properties of the $b^{1} \Sigma_{g}^{+}$state and of the $a^{1} \Delta_{g}-b^{1} \Sigma_{g}^{+}$ transition. In a free $\mathrm{O}_{2}$ molecule this transition is pure quadrupole by nature; in spite of the large quadrupole transition moment $\left(\left\{a^{i} \Delta_{g}\left|e\left(x^{2}-y^{2}\right)\right| b^{1} \Sigma_{g}^{+}\right\}=0,54\right.$ $e \AA^{2}$ ), it determines a rather weak Noxon band (at 1,9 $\mu \mathrm{m})$ with $k_{a-b}=0,0025 \mathrm{~s}^{-1}[8,9]$. Semiempirical configuration interaction (CI) method [8] has predicted that in the collision complex $\mathrm{O}_{2}+\mathrm{H}_{2}$ the Noxon $a^{1} \Delta_{g}-b^{1} \Sigma_{g}^{+}$transition becomes an electric dipole by nature with a transition moment $\left(a^{1} \Delta_{g}|D| b^{1} \Sigma_{g}^{+}\right)=$ $=0,01 \mathrm{e} \AA$, where $D$ is an electric dipole operator [7]. This leads to enhancement of the Noxon band $a^{1} \Delta_{g}-$ $-b^{1} \Sigma_{g}^{+}$transition by five thousand times in respect to free $\mathrm{O}_{2}$ molecule. This enhancement has been observed in solid argon matrices [10] few years after the theoretical prediction [8]. Such prediction can explain the great enhancement of the $a^{1} \Delta_{g} \rightarrow X^{3} \Sigma_{g}^{-}$emission upon collisions as well [7-9]. The singlet $b^{1} \sum_{g}^{+}$state and the ground triplet $X^{3} \Sigma_{g}^{-}$state are mixed by relatively strong spin-orbit coupling (SOC) in a free $\mathrm{O}_{2}$ molecule. With account of SOC by perturbation theory one easily gets [11]

$$
\begin{gathered}
\Psi_{b}=\left|b^{1} \sum_{g}^{+}>+c\right| X^{3} \Sigma_{g, 0}^{-}>, \\
\Psi_{X, 0}=\left|X^{3} \sum_{g, 0}^{-}>-c *\right| b^{1} \sum_{g}^{+}>,
\end{gathered}
$$

where the admixture coefficient

$$
c=\frac{\left(X^{3} \sum_{g, 0}^{-}\left|H_{s o}\right| b^{1} \sum_{g}^{+}\right)}{E\left(b^{1} \Sigma_{g}^{+}\right)-E\left(X^{3} \Sigma_{g, 0}^{-}\right)}
$$

is small, but not negligible. The SOC integral in (3) is equal to $-i \zeta_{o}$, where $\zeta_{o}=153 \mathrm{~cm}^{-1}$ is the SOC constant for the ground state of the $\mathrm{O}\left({ }^{3} \mathrm{P}\right)$ atom [11]. $A b$ initio calculations give larger value for the (3) SOC integral $\left(176 \mathrm{~cm}^{-1}\right)$ [12]. With account of the energy gap $\left(13120 \mathrm{~cm}^{-1}\right)$ one gets $c=-0,013 i$. In Eqs. $(1-3)$ the lowest spin-sublevel $\left(M_{S}=0\right)$ of the triplet $X^{3} \Sigma_{g}^{-}$ state is given. The admixture coefficient (3) is responsible for a big number of spectral properties of the $\mathrm{O}_{2}$ molecule. In particular, it determines intensity of the $b^{1} \Sigma_{g}^{+}-X^{3} \Sigma_{g}^{-}$magnetic transition to the spinsublevel $\left(M_{S}=1\right)$ of the triplet $X^{3} \Sigma_{g}^{-}$state $\left(k_{b-X}=0,08\right.$ $\left.\mathrm{s}^{-1}\right)[8-19]$ and the electric dipole moment of the $b^{1} \Sigma_{g}^{+} \rightarrow B^{3} \Sigma_{u}^{-}$transition [19]. For our purpose it is important that the singlet $b^{\mathrm{l}} \Sigma_{g}^{+}$state admixture to the $X^{3} \Sigma_{g}^{-}$term (2) provides the $a^{1} \Delta_{g} \rightarrow X^{3} \Sigma_{g}^{-}$intensity «borrowing» from the $a^{1} \Delta_{g}-b^{1} \Sigma_{g}^{+}$transition $[7,15]$ ]:

$$
\left(a^{1} \Delta_{g}|D| \Psi_{X, 0}\right)=-c\left(a^{1} \Delta_{g}|D| b^{1} \Sigma_{g}^{+}\right)
$$

Since the $a^{1} \Delta_{g}-b^{i} \Sigma_{g}^{+}$transition intensity is strongly increased in solvent ( $c a .10^{5}$ times), this means the same increase for the $a^{1} \Delta_{g}-X^{3} \Sigma_{g}^{-}$transition. The admixture coefficient (3) is a pure oxygen property and does not depend much on solvent. Thus the theory [8] explains the negligible solvent dependence of the $k_{a-X}$ rate constant [5] as a principal result of a simple approach.

Egorov et. al. [6] first applied the single-photon counting to detect the $a^{1} \Delta_{g} \rightarrow X^{3} \Sigma_{g}^{-}$luminescence in water solvent of organic dye. The sensitizer was excited by a copper vapor laser with $10-\mathrm{kHz}$ repetition rate; about $10^{7}$ laser shots were necessary to accumulate very weak luminescence. Biexponential rise 
ELECTRONIC MECHANISMS OF GENERATION OF LUMINESCENCE

Transition dipole moments $\left(\mathrm{M}_{\mathrm{n}-\mathrm{m}}, 10^{-2}\right.$ debye) induced by collision $\mathrm{O}_{2}+\mathrm{C}_{2} \mathrm{H}_{4}$ at different intermolecular distances (R)

\begin{tabular}{|c|c|c|c|c|c|c|c|}
\hline$n-m$ & $\left\langle\Psi_{n}\right| e r+\Psi_{m}>\| R$ & $3,2 \AA$ & $3,2 \&$ & $3.4 \AA$ & $3,6 \&$ & $3,8 \AA$ & 48 \\
\hline $1-2$ & $M_{\dot{a}-a}$ & 0,0343 & 0,0125 & 0,0045 & 0,0013 & 0,0002 & 0,0009 \\
\hline $1-3$ & $M_{\dot{a}-b}$ & 1,1357 & 0,835 & 0,6497 & 0,5369 & 0,464 & 0,4103 \\
\hline $1-4$ & $M_{\dot{a}-X T}$ & 9,2251 & 5,5781 & 3,2866 & 1,883 & 1,0412 & 0,5512 \\
\hline $1-4$ & $M_{a-c}$ & 7,2578 & 5,731 & 4,3252 & 3,2043 & 2,3761 & 1,7864 \\
\hline $2-3$ & $M_{a-b}$ & 4,3377 & 3,3605 & 2,6061 & 1,9528 & 1,4052 & 0,9798 \\
\hline $4-5$ & $M_{X T-c}$ & 20,1423 & 14,471 & 9,5599 & 5,9227 & 3,4654 & 1,9175 \\
\hline
\end{tabular}

and decay curve of the $\mathrm{O}_{2}\left(a^{1} \Delta_{g}\right)$ with time constants $\tau_{\Delta}$ and sensitizer triplet-state lifetime $\tau_{T}$ were measured accurately varying the $\mathrm{O}_{2}$ partial pressure from 1 to $15 \mathrm{bar} ; 1 / \tau_{\Delta}$ was found to be proportional to $\left[\mathrm{O}_{2}\right]$, whereas $\tau_{\Delta}=3,1 \mu \mathrm{s}$ remained constant. Two main factors contribute to the relative inefficiency of the singlet oxygen deactivation $\left(k_{Q}^{\Delta}\right)$. Firstly, the $\mathrm{O}_{2}$ $\left(a^{1} \Delta_{g}\right)$ excitation energy $(0,98 \mathrm{eV})$ has to be converted into vibrational, rotational and translational energy of the solvent. This explains why the noble gases $(\mathrm{Ne}, \mathrm{Ar}, \mathrm{Kr})$ are the weakest quenchers of $\mathrm{O}_{2}$ $\left(a^{1} \Delta_{g}\right)$ [1]. Secondly, the $a^{1} \Delta_{g} \rightarrow X^{3} \Sigma_{g}^{-}$deactivation is spin-forbidden for quenchers with singlet ground state. Gases with doublet $\left(\mathrm{NO}, \mathrm{NO}_{2}\right)$ and triplet $\left(\mathrm{O}_{2}\right)$ ground states have larger quenching rate than diamagnetic molecules. For $\mathrm{H}_{2} \mathrm{O}$ the quenching rate constant $k_{Q}{ }^{\Delta}=4900 \mathrm{M}^{-1} \mathrm{~s}^{-1}$, for $\mathrm{C}_{6} \mathrm{H}_{6} k_{Q}{ }^{\Delta}=3200 \mathrm{M}^{-1} \mathrm{~s}^{-1}$; these molecules are the most efficient quenchers. Very recently, Andersen and Ogilby reported $k_{b-a}$ values determined by absorption spectroscopy in a number of solvents [20]. A linear correlation fit of $k_{b-a}$ and $k_{X-a}$ values confirmed the conclusions derived by Schmidt $[1,22]$ in the application of the theory $[7$, 14,15 ]. Ratio $k_{b-a} / k_{X-a}$ for individual colliders were determined to be in the range $0,0003-0,0009$ depending on the solvent and detection technique $[1,20$, 22]. This is in line with the theory [8].

Since the $k_{a-X}$ value slightly increases with solvent polarizability [1] a number of different solvent molecules $\left(\mathrm{H}_{2} \mathrm{O}, \mathrm{NH}_{3}, \mathrm{C}_{2} \mathrm{H}_{4}\right.$, decapentaene) have been calculated in collision complexes with $\mathrm{O}_{2}$ by $\mathrm{CI}$ method [8, 21]. It was shown that unsaturated molecules provide stronger enhancement of the $a-b$ and $a-X$ transitions, than the saturated ones $[8$, 221. The decapentaene molecule with a long $\pi$ conjugation system provides ten times stronger enhancement than $\mathrm{H}_{2}$.

In the present work we discuss results of our new systematic $a b$ initio calculations of collision complexes between $\mathrm{O}_{2}$ and dye molecules by $6-311 \mathrm{G}^{*} \mathrm{CI}$ method, based on the restricted open-shelk HartreeFock calculation of the ground triplet state of the complex. Ethene, butadiene and hexatriene have been considered as dienes, free base porphin - as a typical porphyrin dye. A systematic increase of the $a-b$ and $a-X$ transitions probability with increase of $\pi$ conjugation system is confirmed. In Table the results of ethane $\mathrm{HO}_{2}$ collision complex are presented. Only singlet $(S)$ states given in Figure are considered. Table indicates increase of the $S-S$ transition moments, induced by collision, with decrease of the intermolecular distance $R$. Two quasidegenerate $a^{\prime} \Delta_{g}$ states denoted as $a, \dot{a}$ correspond to $A_{1}$ and $B_{2}$ states in the $C_{2 v}$ point group. We use the same type of collision complex as before [15]: the $O=O$ and $C=C$ bonds form a regular trapezium ( $z x$ plane) with $z$-axis $\left(\mathrm{C}_{2}\right.$ symmetry axis) being perpendicular to the ethane plane $(y x)$. The $\mathrm{Cl}$ active space includes $3 \sigma_{g}, \pi_{u}$. $\pi_{g}, 3 \sigma_{u}$ molecular orbitals of $\mathrm{O}_{2}$ and a number of occupied and empty MO of ethane. All single and double excitations are included in our CI method: this gives 9680 configuration state functions for singlet states CI. At large distances $(R=3-4 \AA)$ all states are easily interpreted as excitations inside $\mathrm{O}_{2}$ or ethene molecules (Table). The $a-b$ transition (2-3) is quite strong even at large distance, $R=4 \AA$. Only 1-5 transition $\left(a^{1} \Delta_{g} \rightarrow c^{1} \Sigma_{u}^{-}\right.$excitation inside $\mathrm{O}_{2}$ perturbed by collision) is stronger. This band has been observed in emission for oxygen diluted in $\mathrm{Ar}$ matrix by Okada et al. [20]. In matrix the $a-c$ transition is much stronger than in free $\mathrm{O}_{2}$ in agreement with our results. The 1-4 transition corresponds to cooperative phosphorescence which is shifted by $0,98 \mathrm{eV}$ to the red. It is getting more intense than the $1-5$ transition at $R=3.2 \AA$. Increase of $\mathrm{CI}$ and basis set in our present work lead to more accurate data than before 


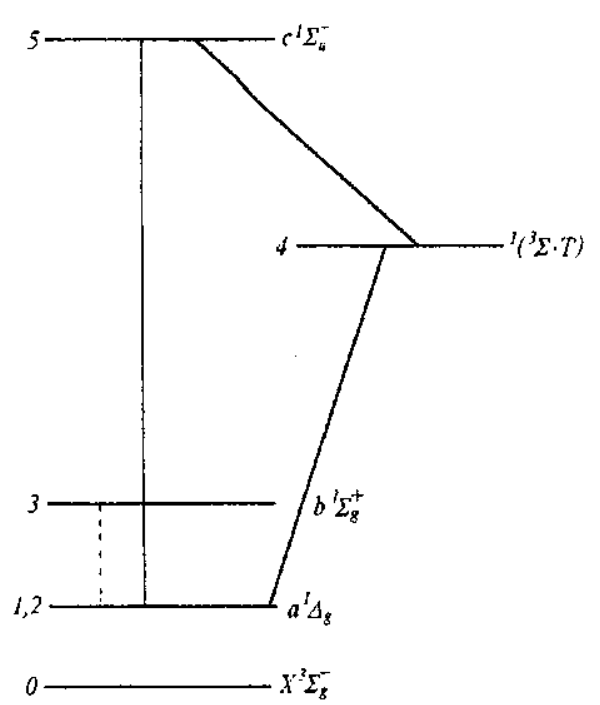

The calculated energy levels in the complex between $\mathrm{O}_{2}$ and dye molecules. "For porphyrins the $E(T)$ is about $1,6 \mathrm{eV}$ and is close to the energy of the $b^{i} \Sigma_{g}^{+}$state. The ground $S_{0}$ state of dye is missed, only the triplet $(T)$ state is shown.

[19] and predict more intense cooperative phosphorescence. The other cooperative transition (4-5) is predicted here for the first time and provides a real sensation since it is extremely intense. For all studied solvents the first excited triplet state $(T)$ is of $\pi \pi^{*}$ nature. It lies lower than the vertically excited $c^{\prime} \Sigma_{u}^{-}$ state. In absorption the $\mathbf{4} \rightarrow 5$ transition can detect the presence of the $T$ excited dye. In etene complex the $4 \rightarrow 5$ transition has $0,86 \mathrm{eV}$ energy. In other dienes it occurs in visible region. With two laser experiments it is possible to produce a pumping of the $c^{1} \Sigma_{u}^{-}$state of $\mathrm{O}_{2}$, which could be very useful for many applications. Firstly it is very reactive in respect to oxidation of organic dye, as we can see it from our computer simulation of reaction with butadiene. Secondly, it can lead to generation of the singlet $a^{1} \Delta_{g}$ state. Thus the quantum chemical calculations can predict the most efficient dye sensibilizer for photodynamic therapy of cancer, instead of the difficult experimental search. This is based on calculation of electric dipole transition moments, induced by collisions $\mathrm{O}_{2}+$ dye; next step is the energy transfer rate estimation by dipoledipole interaction. The second dipole transition moment corresponds to vibrational excitation which comes to the resonance with a proper energetic balance for energy transfer process.

Energy transfer from the triplet-excited dye and $\mathrm{O}_{2}$ molecule to produce the ground $\mathrm{S}_{0}$ state of the dye and the singlet $a^{1} \Delta_{g}$ oxygen is spin allowed and usually is explained by the so-called exchange mecha- nism $[9,20]$. In the model developed before [14] the exchange mechanism of such energy transfer is considered by direct calculation of collision complexes between $\mathrm{O}_{2}$ and organic dye. Forbidden $S-T$ transitions in such complex are getting electric-dipole allowed because of exchange interactions in the open shell system $\mathrm{O}_{2}+$ dye. Then the energy transfer is described by the usual dipole-dipole interaction model [20], where the collision-induced transition moments are taken into account for the resonance intermolecular interaction estimation [14]. Now we shall apply this model. The 1-4 transition is the most intense one (Table); it can interact with the resonance vibrational transition inside the dye molecule, which can be an overtone or combination of $\mathrm{C}-\mathrm{H}$ vibrational modes. Similar results have been obtained for other dyes and the increases of the 1-4 transition moments $M_{i-X T}$ with the size of $\pi$-conjugation chain goes in parallel with the increase of polarizability of the dye.

Thus our theory predicts that mostly the singlet $a^{1} \Delta_{g}$ oxygen can be generated during the energy transfer act, not the $b^{1} \Sigma_{g}^{+}$oxygen. This is in agreement with many experimental data, though the direct measurements of the energy transfer rate constants are very difficult $[1]$.

The large 1-4 transition moment $M_{i-X T}$ can be used for additional generation of the triplet state using additional laser impuls with the frequency $\mathrm{h} v=$ $=E(T)-E\left(a^{1} \Delta_{g}\right)$. For porphyrins it is about $0,6 \mathrm{eV}=$ $=4800 \mathrm{~cm}^{-1}$, thus it comes into IR region. Tuning such laser we can select those dyes which correspond to the resonance. It means that the singlet oxygen $\left(a^{t} \Delta_{g}\right)$ being generated in the first cycle of photodynamic therapy of cancer can produce the triplet excited state of the dye in photosensitization experiments in solvents.

Let us provide some conclusions from previous experimental studies and our new findings in the context of photodynamic therapy of cancer. Relative efficiency of the singlet $a^{1} \Delta_{g}$ oxygen generation by the dye can be predicted on the ground of quantum chemical calculation of the following factors 1) $\mathrm{CI}$ calculation of the 1-4 transition moment; 2) calculation of vibrational frequencics and normal modes of the dye in the singlet ground state and in the triplet excited state; 3) calculation of the dipole-dipole interaction between guantum transition moments and estimation of the energy transfer ratc constants. 


\section{Б. Ф. Мінасв, Л. Б. Ящцкк}

Можливі електронні механізми утворення і гасіння свічення синглетного кисню у фотодинамічній терапіі: дослідження методом $a b$ initio

\section{Резюме}

На основі аb initio квантово-хімічних розрахунхів передбачено істотне зростанкя ${ }^{I}\left(a^{1} \Delta_{\mathrm{g}} \cdot S_{0}\right) \rightarrow{ }^{1}\left(X^{3} \Sigma_{\mathrm{g}}^{-} \cdot T\right)$ переходу в комплексі зіткнення $O_{2}$ з органічним барвником, де $T-$ - ее триплетний збуджений, а $S_{0}$ - основний синглетний стан барвника. Індукований зіткненням електродипольний момент переходу залежить від поляризованості барвника $і$ може бути використаний для оцінки констант перенесення енергії. Квантовохімічними розрахунками мохна точніше передбачити найефективніний барвник-сенсибілізатор для фотодинамічної терапіï рака, ніж складними експериментальними дослідженнями. Запропоновано деякі нові ідеї стосовно механізміз додаткового моделювання стадї̈ активацї кисню.

Ключові слова: синслет, триплет, комплекс зіткнення, момент переходу, спін-орбітальна взаємодія.

\section{Б. Ф. Минаев, Л. Б. Ящук}

Возможные электронные механизмы образования и тушения свечения синглетного кислорода при фогодинамической терапии: исследование методом $a b$ initio

\section{Резюме}

На основании аb initio квантояо-химических расчетов предсказано сильное уөеличение ${ }^{I}\left(a \Delta_{\mathrm{g}} \cdot S_{0}\right) \rightarrow{ }^{1}\left(X^{3} \Sigma_{g}^{-} \cdot T\right)$ перехода в комплексе столкновения $\mathrm{O}_{2}$ с органическим красителем, где $T$ - триплетное возбужденное, а $S_{0}$ - основное синглетное состояние красителя. Индуцированный столкновением электродипольный момент перехода зависит от поляризуемости красителя и может быть использован для оџенки констант переноса энергии Квантово-химическими расчетами можно точнее предсказать наиболее эффективный краситель-сенсибилизатор для фотодинамической терапии раха, нежели сложными эксперижентальными исследованиями. Предложены некоторые новье идеи относительно механизмов дополнительного моделирования стадии активачии кислорода.

Ключевые слова: синглет, триплет, комплекс столкновения, момент перехода, спин-орбитальное взаимодействие.

\section{REFERENCES}

1. Schweitzer C., Schmidt R. Physical mechanisms of generation and deactivation of singlet oxygen // Chem. Rev.-2003.103.-P. $1685-1757$.

2. Datta D., Vaidehi N., Xu X., Goddard W. A. Mechanism for antibody catalysis of the oxidation of water by singlet dioxygen // Proc. Nat. Acad. Sci. USA.-2002.-99.-P. 2636-2642.

3. Redmond R. W., Gamlin J. N. Singlet oxygen photochemistry and its application // Photochem. Photobiol.-1999.-70.P. $391-400$.

4. Krasnovsky A. A., Jr. Luminescence of singlet oxygen during energy iransfer from photoexcited pigments in solution // Biofizika.-1976.-21.-P. 748-755.

5. Krasnovsky A. A., Jr. Quantum yield of photosensitized luminescence and radiative lifetime of singlet molecular oxygen in solutions $/ / \mathrm{J}$. Chem. Phys. Lett. $-1981 .-81 .-\mathrm{P} .443-$ 445.

6. Egorov S. Y., Kamalov V. F., Koroteev N. I., Krasnovsky A. $A ., J r$, Toleutaev B. N., Zinukov $S . V$. Rise and decay kinetics of photosensitized singlet oxygen luminescence in water. Measurements with nanosecond time-correlated single photon counting technique $/ / \mathrm{J}$. Chem. Phys. Lett.-1989.-163.P. $421-424$.

7. Minaev B. F. USSR-All-Union School on Quantum Chemistry: Abstracts. - Karaganda, 1982.

8. Minaev B. F. Theoretical analysis and prognostication of spin-orbit coupling effects in molecular spectroscopy and chemical kinetics // Dr. Sc. Thesis. N. N. Semenov / Institute of Chemical Physics.-Moscow, 1983.

9. Sveshnikova E. B., Minaev B. F. Mechanism of nonradiative quenching of singlet oxygen in solution // Opt. Spectrosc.-1983.-54.-P. 320-323.

10. Becker A. C., Schurath U., Dubost H., Galaup J.P. Luminescence of metastable $16 \mathrm{O}_{2}\left(18 \mathrm{O}_{2}\right)$ in solid argon: Relaxation and energy transfer $/ / \mathrm{J}$. Chem. Phys. - 1988.-125.P. 321-336.

11. Minaev $B . F$. Intensity of singlet-triplet transitions in the oxygen molecule and selective effect of an external heave atom // Opt. Spectrosc.-1978.-45.-P. 936--942.

12. Klotz $R$., Peyerimhoff $S$. Theoretical study of the intensity of the spin- or dipole forbidden transitions in $\mathrm{O}_{2} / / \mathrm{Mol}$. Phys.-1986. - 57.-P. 573-594.

13. Minaev B. F., Agren $H$. Collision inducted $b^{1} \Sigma_{g}^{+} \rightarrow a^{1} \Delta_{g}$; $b^{1} \Sigma_{g}^{+} \rightarrow X^{3} \Sigma_{g}^{-}$and $a^{1} \Delta_{g} \rightarrow X^{3} \Sigma_{g}^{-}$transition probabilities in molecular oxygen // J. Chem. Soc. Faraday Trans. -1997.-93.P. $2231-2239$.

14. Minaev $B . F$. Quantum-chemical investigation of the mechanisms of the photosensitization, luminescence, and quenching of singlet ${ }^{1} \Delta_{g}$ oxygen in solutions // J. Appl. Spectrosc. - 1985.42. -P. $518-526$

15. Minaev $B$. $F$. The theory of solvent influence on radiative transition $a^{1} \Delta_{g} \rightarrow X^{3} \Sigma_{g}^{-}$probability in molecular oxygen // Opt. Spectrosc. -1985 . -58 .-P. $1238-1246$.

16. Minaev $B$. F. Ab initio study of the ground state properties of molecular oxygen // Spectrochim. Acta, A.-2004.-60.P. $1027-1041$.

17. Minaev B. F. Oxygen absorbtion below and near the Herzberg I continuum. $A b$ initio calculation of the transitions probability from metastable states $/ /$ J. Chem. Phys. $-2000 .-252 .-$ P. 25-33.

18. Minaev B. F., Minaeva $V . A$. MCSCF response calculations of the excited states properties of the $\mathrm{O}_{2}$ molecule // Phys. Chem. Chem. Phys.-2001.-3.-P. 720-729.

19. Minaev $B$. $F$. The singlet oxygen absorption to the upper state of the Shumann-Runge system: The $B^{3} \Sigma_{u}^{-} \rightarrow a^{1} \Delta_{g}$ and $B^{3} \Sigma_{u}^{-} \rightarrow$ $b^{i} \Sigma_{g}^{+}$the transitions intensity calculation // Phys. Chem. Chem. Phys.-1999.-1.-P. 3403-3411.

20. Minaev B. F., Kobzev G. $I$. Response calculations of electronic and vibrational transitions in molecular oxygen induced by interaction with noble gases // Spectrochim. Acta, A.-2004 59.-P. 3387-3410.

21. Minaev B. F., Mambeterzina $G$. $K$. Oxygen complexes with naphthalene and decapenthaene studied by configuration interaction method // Photoprocesses in atomic and molecular systems.-Karaganda: KGU, 1984.-P. 35-41.

22. Schmidt $R$. Comments on *Analysis of mixed solvent effects on the properties of singlet oxygen» // Chem. Phys. - 2004.304.-P. 315-316.

УДК $541.5: 539.19$ Надійшла до редакції 20.06.05 